\title{
Gender Differences in Teaching Learning Process Based on Inquiry Model
}

\author{
Maharani Dalimunthe \\ English Applied Linguistics Study \\ Program \\ State University of Medan \\ Medan, Indonesia \\ maharanidalimunthe88@gmail.com
}

\author{
Anni Holila Pulungan \\ English Applied Linguistics Study \\ Program \\ State University of Medan \\ Medan, Indonesia
}

\author{
Zainuddin \\ English Applied Linguistics Study \\ Program \\ State University of Medan \\ Medan, Indonesia
}

\begin{abstract}
This research deals with gender differences of male and female teachers in teaching learning process at SMP ALWASLIYAH 29 TELADAN. The objective of this study was to investigate types of utterances of male and female teachers in teaching learning process based on inquiry model. Case study was conducted for this research. The data of this research were utterances of male and female teachers in teaching learning process. The data were collected by audio recording. The results of this research showed that the features of utterances that have been found in male and female teachers in teaching learning process. Male and female teachers in delivering their utterances used rapport and report talk. Male teachers used rapport talk in delivering their utterances. Meanwhile, female teachers use report talk in delivering utterances to their students
\end{abstract}

Keywords-gender differences; teaching learning process; inquiry model

\section{INTRODUCTION}

Language is an important thing to do the communication in daily life. Without the language we cannot communicate with others. In daily life, each person has different style in communication with other people. Which is often founded from gender. Tannen [1] states that the male and females in their ways in communication, males tend to use language to gain status, while females use the language to negotiate closeness and intimacy. Females use rapport talk to build and maintain relationships, while men use report talk to communicate factual information.

Based on the theory about male and female, this study focuses on differences between male and female teachers in teaching learning process based on inquiry model. So, in this research researcher will analyze features of male and female teachers' utterances in teaching learning process based on inquiry model, the ways male and female teachers in teaching learning process based on inquiry model and the reason of male and female teachers in teaching learning process

Gender can also be find in class like teaching learning process. In teaching learning process, teachers can control their students of communication. Teachers decide who talks, when they talk, and how to control the children when they are working together.
Brown [2] states that one of the important stages in a successful teaching and learning process is classroom management which encompassing the abundance of factors ranging from how the teacher physically arranging the classroom to how to create classroom energy. It shows that in teaching learning process teachers must be active because the teacher cause an energy for active students. The findings of such research can prove that gender can be found anywhere as in the classroom which is certainly in teaching learning process.

Based on explanation, the researcher interest in analyzing gender differences in teaching learning process based on inquiry model. Model is a series of presentation of teaching materials used by teachers in teaching learning process both directly and indirectly. Hosnan [3] suggests that learning model is a conceptual/operational framework, which describes a systematic procedure in organizing learning experiences to achieve certain learning goals and serves as a guide for instructors in planning, and carrying out learning activities. It is aims to achieve something. Because by using the model the teacher can achieve goals in learning. It means that a way that aims to achieve something. Because by using the model the teacher can achieve the goals in learning. It can be simply that model is a way that can facilitate us in something especially for students.

Inquiry is a style or model of teaching where the learner with minimum guidance from the teacher seeks to discover and create answers to a recognized problem through procedure of making a diligent search. Trianto [4] states that inquiry means a series of learning activities that involve a maximum of all students' ability to investigate systematically, critically, logically, analytically, so that they can formulate their own authors with confidence. The main objectives of inquiry learning activities are (a) maximum student involvement in the process of learning activities, (b) the direction of activities logically and systematically on learning objectives, and (c) developing student confidence in what is found in the inquiry process.

In the study of gender differences, there are numerous studies that have described and raised many issues on the different their research. Svric and Jurcic [5] discusses some male politicians show characteristic of female gender speech 
style in their political discourse and vice versa. The female politician also use mixing the speech style using report talk and female politician more frequently use the discourse strategies which are typical for male politician than vice versa.

Ubando [6] conducted a study entaitled Gender Differences in Intimacy, Emotional Expressivity, and Relationship Satisfaction found that males have a more positive perspective of their own intimacy in relationships while women have a more negative perception of their own intimacy and under the category of emotional expressivity, men self-reported higher for verbal and nonverbal affection while women self-reported higher for supportiveness.

The data taken from teaching learning process based on inquiry model in record and transcribed. As this research focus on utterances male and female teacher, the researcher analyzes and clarifies what the features of male and female teachers' utterances in teaching learning process based on inquiry model proposed by Tannen's theory.

\section{REVIEW OF LITERATURE}

\section{A. Teaching Learning Process}

Slameto [7] states that learning is a process carried out by someone to obtain a change in new behavior as a whole, as a result of his own experience in interaction with his environment. It means that learning does not mean making changes to student behavior, but learning means that there is a connection to knowledge that is already known and unknown, learning requires time and place, in learning there are visible signs that student behavior changes as a result of the process learning, behavior can be seen by comparing conditions before and after the learning process takes place.

In the teaching and learning process, the teacher has the duty to encourage, guide, and provide learning facilities for students to achieve goals. The teacher has the responsibility to see everything that happens in the classroom to help the development process of students. From the opinions above, it can be concluded that the teaching and learning process is a process that contains a series of actions of teachers and students on the basis of reciprocal relationships, Slameto. It mentions that the role of a teacher is very large. Where a teacher will see all students learning and achievement is something that is important to note. And the teacher must be able to understand that the feelings and attitudes of students will be seen and have a strong influence on the learning process. In teaching learning processes the teachers often use strategy and models. Strategy and models have different meanings.

\section{B. Model}

Sanjaya [8] states strategy is a general pattern of sequences of activities that must be carried out to achieve certain goals. It means that series is a demand which must be done so that what is desired is achieved and the intent of the general pattern, because a strategy in essence has not led to things that are practical, still in the form of a plan or overall picture. Whereas to achieve goals, strategies are arranged to describe systematic procedures in helping student learning efforts, organizing learning experiences, organizing and planning instructional materials to achieve certain learning goal.

While model is a series of presentation of teaching material that covers all aspects before being and after learning that is done by the teacher and all related facilities that are used face-to-face in the teaching and learning process. Trianto states that learning models are conceptual frameworks that describe systematic procedures in organizing learning experiences to achieve specific learning goals, and serve as guidelines for learning designers and instructors in carrying out teaching and learning activities. It explains that the model is a series of learning that is designed as a rule of activity in learning.

From the explanation above, the experts have stated that model have meaning and purpose. In this study researchers will use a model. In teaching learning process the teacher always leaning model to achieve the learning goals. So students can enjoy learning fun. Theoretically the teacher knows all about learning model.

\section{Learning Models}

Learning model is a pattern of interaction between students and teachers in the classroom that involves approaches, strategies, methods, learning techniques applied in the implementation of teaching and learning activities. Every teachers use a model to achieve learning and now the education curriculum uses curriculum 2013. In the 2013 curriculum learning models have been specified in kind.

Trianto states that problem based learning model is a learning model that is based on the many problems that require authentic investigation, namely investigations that require real solutions to real problems. In this model, students work on authentic problems with the intention of developing their own knowledge, developing inquiry and high-level thinking skills, developing self-reliance and self-confidence.

Concept of problem-based learning is an instructional model that presents a problem conceptual thus simulating learners to learn. In classes the implement problem based learning, students work in teams to solve real-world problems learning model is challenging learners to learn, how to learn, to work in groups to find solutions to real-world problem. Given issue is used to bind the learners in curiosity at the intended learning, problem given to the students before the students learn concept or materials relating to the problem to be solved.

The learning model is clarified as trying to teach students to recognize problems, formulate problems, find solutions or test temporary answers to a problem or question by conducting an investigation (finding facts), which presents it verbally or in writing. Based on this explanation, the learning model used in this study is inquiry.

\section{Inquiry Model}

Inquiry comes from the word "to inquire" which means participating, or being involved, in asking questions, seeking information, and conducting investigations. Inquiry is a method of teaching that involves students to the fullest. 
Inquiry model makes students more active to solve a problem more systematically.

Hosnan argues that inquiry is a series of learning activities that emphasize the process of critical and analytical thinking to find and find out for themselves the answers to a questioned problem. The thinking process itself is usually done through question and answer between the teacher and students. Learning activities are interactions carried out between teachers and students in a teaching to realize the learning objectives that have been set. There are several things that must be considered by the teacher in teaching, one of which is the learning method. The choice of method is related to the way the teacher displays the teaching in accordance with certain situations and conditions, so that the learning objectives can be achieved optimally.

In teaching learning process, apart from using the strategy or model the teacher also uses the curriculum so that learning is achieved. The curriculum has been established in Indonesian education and applied by the government. Sailor and Alexander states that curriculum is defined reflects volume judgments regarding the nature of education.

The curriculum is a subject and subject matter which is taught by the teacher and learned by students. In terms of terminology, the curriculum means an educational program that contains various teaching materials and learning experiences programmed, planned and designed systematically on the basis of prevailing norms and used as a guide in the learning process for educators to achieve educational goals. For this reason, at present, Indonesia uses Curriculum 2013, this curriculum is determined after Curriculum 2006 (KTSP) which has been in effect for approximately 6 years.

\section{E. Curriculum 2013}

The curriculum 2013 is a curriculum of values that occupied by character building. The values can be tracked from the Core Competences, abbreviated with KI-1 to KI-4. $\mathrm{KI}-1$ is designed for spiritual competence, KI-2 for social competence, $\mathrm{KI}-3$ refers to knowledge competence and KI-4 is for learning process through with the KI-3, KI-2, and KI-1 can be observed. The learning paradigm encompass direct and indirect learning model, and indirect learning model refers to KI-1 and KI-2. These two competences have no specific learning materials as it is integrated into cognitive and psychomotor domains. This formulation is aimed at reducing or eliminating verbalism in learning. Basic competence which is abbreviated with $\mathrm{KD}$ is the reference for teachers to develop achievement indicators. $\mathrm{KD}$ in $\mathrm{KI}-1$ and $\mathrm{KI}-2$ is the accumulation of $\mathrm{KD}$ in $\mathrm{KI}-3$ and $\mathrm{K} 1-4 . \mathrm{KD}$ in $\mathrm{KI}-3$ is linear with $\mathrm{KD}$ in $\mathrm{KI}-4$ and the number of $\mathrm{KD}$ in $\mathrm{KI}-3$ is equally sized with the number of KD in KI-4. To map, KD3.1 foe example is associated with KD4.1, KD3.2 is associated with KD4.3, and so forth.

So from the explanation above, it can be seen that C-13 is designed to revise or to correct the mistakes of the competence "meanings" in the previous curriculum, Hapsari [9]. It means that in curriculum 2013 is plans which will be the goal to solve problems in learning so that the goals are achieved.

\subsection{Scientific Approach in Curriculum 2013}

Permendikbud No.81 tahun 2013 lampiran IV states that this approach is claimed to be more affective in increasing students' learning outcomes than the traditional one. This approach is also considered relevant with the idea that learning is scientific process in the classroom. Therefore, scientific approach in curriculum 2013 must be applicable in all subjects including English. The criteria and the steps of scientific approach in teaching and learning process are elaborated in the following. There are three points that become the focus in teaching and learning process with scientific approach. They include attitudes (affective), skills (psychomotor) and knowledge (cognitive).

\section{F. Gender}

Gender is different with sex. Romaine [10] states that gender refers to the socially constructed roles of and relationships between men and women or male and the female. These concepts have in the past decades been denoted by two separate terms, sex and gender. Cameron states that sex refers to the body, biology, while gender is a socially mediated expression of the biological given sex.

\subsection{Men and Women in Communication}

In communication, there is conversational style. Tannen states that conversational style is the basic tools which people communicate anything which people communicate anything what is said some way, that way is style. It shows that conversational style is style of male and female speakers in communication. Some linguist state that male and female has different way in doing conversation. The reason men and women communicate in different ways range from biological differences, parental differences, education and birth order to cultural conditioning by society, the media and history, Gray [11].

Tannen finds some differences between men and women in communication such as; status versus support, independence versus intimacy, advice versus understanding, information versus feeling, order versus proposal, conflict versus compromise.

Tannen's theory is useful in understanding the other gender's way of communicating, preventing miscommunication between gender and help to promote mutual respect by showing how people should appreciate and the style of communication of both gender. Both of genders have their own characteristic in communication. There are the features of report talk and rapport talk in communication.

\subsection{The Reason of Male and Female Speak Differently}

Tannen state that for most women, the language of conversation is primarily a language of rapport, it is a way of establishing connections and negotiating relationship, while for most men, talks primarily means to preserve independence and negotiate and maintain status in a hierarchical social order. Men often dominate conversation in public, because they use conversation to establish status. Women, on the other hand, often listen more because they have been socialized to be accommodating. Women are trained to look for connection 
in their interaction, they make efforts to raise topics and to get others to take them up, in order to equalize speakers' turns. Men are being trained to look for power in their interaction, try to control the topic. It is mentioned that women tend to be acquired the connection in their interaction, they establish it to promote the intimacy, cooperative and warm feeling to their partner of conversation itself. Whereas, men raise up the power to promote their accomplishment and individual aim. They tend to be competitive to control the topic of conversation.

\section{METHODOLOGY}

This study used qualitative research design in this research because the research was intended to be describe information about certain phenomenon that happened when a research is being conducted. Qualitative design is conducted in this study to answer the research questions of this study. Miles, Huberman, and Saladana [12] explained text by applying this design, one can preserve chronological flow, see which event led to which consequences clearly and also get faithful explanation. Bogdan and Biklen [13] state that qualitative is descriptive, where the data is in the form of words or pictures rather than numbers. It means that qualitative design can be used as method of this research. The research data attempted to analyze different between male and female teachers in teaching learning process based on inquiry model that gotten from record transcription of teaching learning process.

The data take from record male and female teachers in teaching learning process based on inquiry model. In this research the researcher transcribed and then analyzed. The data of this research were sentences that contains of different between male and female teachers in teaching learning process based on inquiry model. Bogdan and Biklen stated that the term data refers to the rough material basis of analysis. The data includes such as utterances transcripts and interview transcripts. There were six teachers, means the teachers who teach subject matter in SMP AL-WASLIYAH 29 MEDAN. Which three male teachers and three female teachers. Guy and Dhiel stated that the minimum sample size of descriptive qualitative research that is acceptable will be $10 \%$ of population. It means that from 12 teachers, the researcher chooses 6 teachers to be recorded in teaching learning process. Because the subject matter of the teacher, there are six teachers so researcher takes all the teachers as the subject of this research.

These were initial of teachers as subject in this research, DA is the first teacher, and he was graduated from STOK BINAGUNA. DA is 26 years old. The second teacher is MT graduated from UNIMED. MT is 35 years old. MAN is the third teacher graduated from UNIMED. MAN is 30 years old. The fourth teacher was FN graduated from UNIMED and she is 37 years old. MZ is the fifth teacher graduated from USU and he is 23 years old. The sixth teacher was ZNO and she graduated UMN. She is 24 years old. These teacher as the subjects in this research. This research is at SMP ALWASLIYAH 29 MEDAN on Jl. StadionTeladanNo. 12
KelurahanTeladanKecamatanMedan Barat. Medan Kota, Medan. Academically, the researcher choose the location of this research is at SMP AL-WASLIYAH 29 MEDAN, namely the choice of location was based on several things: this school is a school that is in the field region is very close to reach the researcher, researcher know that in this school has process and different learning times such as general lessons and Islamic lessons have no comparison, which are generally found in kindergarten, elementary school, junior high school and vocational high school education. In addition this school is an Islamic school with the majority of all Muslim and this school aims to create a noble child who also makes a great child. For this reason, researcher choose the research site.

In this research, eighth grade is as subject of this research because these classeshave use curriculum 2013 which in this research use inquiry model, it is learning model in curriculum 2013 and eight grade the students are more responsive because in this model they are required to think critically. Bogdan and Biklen states that qualitative research has the natural setting as the direct source of the data and the researcher is the key of instrument, the instrument of this research is the researcher himself. The data of this study collected in observation. This research used observation method as proposed by Sudaryanto and document analysis method as suggested by Bogdan and Biklen. The researchers used observation and documentation technique to collect the data. The data of this research were between male and female teachers found in the record of teaching learning process based on inquiry model. The data of this research was collected by following steps:

1. Recording

2. Transcribing

3. Analyzing

Bogdan and Biklen explain the analysis in qualitative involves working with data, organizing them breaking them into manageable units, synthesizing them, searching for patterns, discovering what is important and what is to be learned and deciding what explained. In this research, it is the process to select the utterances of male and female teachers in teaching learning process based on inquiry model in record as the data based on Tannen's theory. Then, the researcher made data display by listing male and female teachers utterances and display it.

According to Miles, Huberman and Saldana in analysis of qualitative data consists of three concurrent flows of activity namely 1) data condensation, 2) data display, and 3) conclusion drawing or verification.

1) Data condensation refers to the process of selecting, simplifying, abstracting and transforming data.

a. Selecting in this research means choosing the data. Utterances can be write in words or phrases.

b. Focusing means to pay in the particular attention to the suitable data. In this study, the researcher only focuses on different between male and female teachers from 
record in teaching learning process based on inquiry model.

c. Simplifying means make the data simpler or easier to understand. In this study, the data that has been collected need to be simplified in order to make it easier to be analyzed. To simplify, the data is classified into some classifications of different between male and female teachers.

d. Abstracting means summarize the data. To summarize the data in this research, the researcher used the data which is based on existing theories about gender differences.

e. Transforming means to make a through or dramatic change in the form and appearance. In the last step the data as male and female teacher's utterances from recordand it is analyzed into next step. In this study, male and female teacher's utterances in record and it is analyzed that appears is condensed by grouping the data, coding the data, focusing it to different between male and female teacher.

2) Data display means to organize assembly of information that permits conclusion drawing. Related to this study, after identifying the data, the data are displayed as organized information leading to the conclusion drawing. In this step, the researcher makes data display by listing the classification of different between male and female teachers. Then, the data are displayed in the form of table and figure.

3) Verification/conclusion drawing means that the analysis should be allowed to begin to develop conclusions regarding the study. In this study to enhance this procedure, the conclusions of the data are drawn and verified through studying the theories. The researcher clarifies and concludes the classification of different between male and female teachersfound record in teaching learning process based on inquiry model, the way male and female teachers in teaching learning process based on inquiry model, and reveal the reason of male and female teachers in teaching learning process based on inquiry $\mathrm{m}$ Lincoln and Guba [14] stated that trustworthiness of a research study is important to evaluating its worth. The aim of trustworthiness of a research study is important to support the argument that the in quirt's finding are worth paying attention to Lincoln and Guba. It can be achieved through checking the credibility, transferability, dependability, and conformability, as the following:
a. Credibility
b. Transferability
c. Dependability
d. Conformability

\section{FINDING AND DISCUSSION}

After analyzing the data, the data are classified based on the features of utterances used by male and female teachers.
There are features of talk used by male and female teachers. Report and rapport talk that have been found in teaching learning process based on inquiry model. Male teachers used rapport talk, meanwhile female teachers used report talk, and the percentage of using both talk types seen in Table 1 and 2 .

TABLE 1. THE FEATURES OF RAPPORT TALK USED BY MALE TEACHERS

\begin{tabular}{lcc}
\hline Report Talk & Total & \% \\
\hline Direct Request & 17 & 32 \\
\hline $\begin{array}{l}\text { Longer Talk in } \\
\text { Public Context }\end{array}$ & 5 & 9 \\
\hline $\begin{array}{l}\text { Speech Includes } \\
\text { Slang or Swear } \\
\text { words, Teasing } \\
\text { and Banter }\end{array}$ & - & - \\
\hline $\begin{array}{l}\text { Giving Advice } \\
\text { to Solve }\end{array}$ & 17 & \\
Problem & & 32 \\
\hline $\begin{array}{l}\text { Mixing } \\
\text { Business and } \\
\text { Non-business } \\
\text { Talk }\end{array}$ & - & - \\
\hline $\begin{array}{l}\text { Rarely Give } \\
\text { Praise or } \\
\text { Compliments }\end{array}$ & & \\
\hline $\begin{array}{l}\text { Showing } \\
\text { Authority }\end{array}$ & 6 & 11 \\
\hline Total & & \\
\hline & 9 & $\mathbf{1 0 0}$ \\
\hline & $\mathbf{5 4}$ & \\
\hline & & \\
\hline & & \\
\hline
\end{tabular}

In Table 1 showed that the percentages of rapport talk, establishing Relationship is highest used male teachers. Male teachers can be seen closeness and intimate with their students. Apologizing is seldom to be used because in teaching learning process this type used by male teachers at the last meeting. In this table above is total of all percentages the features of rapport talk used male teachers which from the data, it can be seen that there are $14(17 \%)$ of Use Qualifiers, Apologizing is $2(2 \%)$, Taking Blame is $6(7 \%)$, Thanking is 4 (5\%), Maintaining an Appearance of Equality, Downplaying Qualifications is 13 (15\%), Establishing Relationship is 31 (37\%), and Downplaying Authority is $14(17 \%)$.

Table 2 the percentages of report talk, direct request is highest used female teachers. Which female teachers look direct, power and to the point in speaking. Because female teachers want to see their status are a teacher. Speech Includes Slang or Swear Words, Teasing and Banter is nothing to be used. In teaching learning process teachers cannot have Speech Includes Slang or Swear Words, Teasing and Banter so that the students is afraid to teachers. In this table is total of all percentages the features of report talk used female teachers which from the data, it can be seen that there are $68(47 \%)$ of Direct request, Longer Talk in Public Context is $6(5 \%)$, Giving Advice to Solve Problem is 39 (27\%), Mixing Business and Non-Business Talk is $1(1 \%)$, Rarely Give Praise or Compliments is 12 (8\%), Showing Authority is $18(12 \%)$. 
Relationship is $12(32 \%)$, and Downplaying Authority is 7 (18\%).

TABLE 2. THE FEATURES OF REPORT TALK AND RAPPORT TALK USED BY FEMALE TEACHERS

\begin{tabular}{lcc}
\hline Report Talk & Total & \% \\
\hline Direct Request & 68 & 47 \\
\hline $\begin{array}{l}\text { Longer Talk in } \\
\text { Public Context }\end{array}$ & 6 & 5 \\
\hline $\begin{array}{l}\text { Speech Includes } \\
\text { Slang or Swear } \\
\text { words, Teasing and } \\
\text { Banter }\end{array}$ & - & - \\
\hline $\begin{array}{l}\text { Giving Advice to } \\
\text { Solve Problem }\end{array}$ & 39 & \\
\hline $\begin{array}{l}\text { Mixing Business } \\
\text { and Non-business } \\
\text { Talk }\end{array}$ & 1 & 27 \\
\hline $\begin{array}{l}\text { Rarely Give Praise } \\
\text { or Compliments }\end{array}$ & 12 & 1 \\
\hline Showing Authority & 18 & 8 \\
\hline Total & $\mathbf{1 4 4}$ & 12 \\
\hline
\end{tabular}

\section{ACKNOWLEDGMENT}

The writer would like to express respectfulness to Dr. Anni Holila Pulungan, M.Hum and Prof. Dr. Zainuddin, M.Hum as her thesis advisor for guiding her to accomplish her thesis and for giving useful knowledge and suggestions.

\section{REFERENCES}

[1] Tannen, D. 1990. You Just Don't Understand: Women and Men in Conversation. New York: Ballantine Books.

[2] Brown, H. Douglas. 2001. Principles of Language Learning and Teaching, Fifth Edition. San Francisco, State University.

[3] Hosnan. 2014. Pendekatan Saintifik dan Kontekstual dalamPembelajaran Abad 21. Jakarta: Ghalia Indonesia.

[4] Trianto, (2007). Model-Model Pembelajaran Inovatif Berorientasi Kontruktivistik. Prestasi Pustaka: Jakarta.

[5] Sivric, Marijana and Jurcic, Dijana. 2014. Gender Differences in Political Discourse. Journal of Foreign Language Teaching and Applied Linguistics. DOI Number: 10.14706? JFLTAL152227.

[6] Ubando, M. 2016. Gender Differences in Intimacy, Emotional Expressivity, and Relationship Satisfaction. Pepperdine Journal of Communication Research: Vol. 4, Article 13.

[7] Slameto,2003. Belajar dan Faktor-faktor yang Mempengaruhinya. Jakarta: RinekaCipta.

[8] Sanjaya, W. 2008. Strategi Pembelajaran Berorientasi Standar Proses Pendidikan. Jakarta: KencanaPrenada Media Group.

[9] Hapsari, A. 2013. Making sense the Character Building in the Curriculum Framework: Conceptual Culture as A Local Wisdom and Culture as the Product of Interaction. Proceedings 60th TEFLIN International Conference: Achieving International Standards in Teacher Education, (pp. 360-364). Universitas Indonesia, Jakarta.

[10] Romaine, S. 1994. Language in Society: An Introduction to Sociolinguistics. New York, NY: Oxford University Press.

[11] Gray, J. 1992. Men are from Mars, Women are from Venus. New York: Harper Collins.

[12] Miles, M. B. Huberman, A. M. and Saldana, J. 2014. Qualitative Data Analysis, A Methods Sourcebook, Third Edition. Sage Publications, Inc.

[13] Bogdan, R.C. and S.K, Biklen. 1992. Qualitative Research for Education: An Introduction to Theory and Method. Boston: Allyn and Bacon, Inc.

[14] Lincoln, I \&Guba, EG. 1985. Naturalistic Inquiry. Baverly Hills, London: Sage Publications. 